\author{
VI International Forum on Teacher Education
}

\title{
A Comparative Study of the Working Conditions of Science Teachers
}

\author{
Vyacheslav V. Utemov* \\ Vyatka State University, 610000,Kirov(Russia), 36 Moskovskaya street,vv_utemov@vyatsu.ru
}

\begin{abstract}
Effectiveness of instruction in science education largely depends on whether the teachers are satisfied with their working conditions. Consequently, administrative measures aimed at improving working conditions for teachers will also improve the quality of science teaching. The students of teachers, who have the same experience, similar qualifications and some other characteristics, achieve different learning outcomes. We can specify a set of working conditions that influence the effectiveness of science training and the quality of educational programs. In this study, science teachers are teachers of Physics, Chemistry, Biology, Anatomy, Ecology, and other related subjects. Accordingly, the article is aimed at analyzing the indicators of teacher working conditions in science education and developing a system of organizational and managerial measures to support the work of science teachers on the basis of these indicators. The research methods are data collection by means of a questionnaire survey of teachers and other school staff, analysis of the characteristics of science teaching, modeling and statistical analysis of the research data. The study was conducted in 2019 - 2020; 1,146 employees of secondary schools of European Russia were involved in the study, including 310 science teachers. The author of the article has arrived at the following conclusion: the most significant motives in choosing the profession of a science teacher are the possibility to influence the child development and to participate in solving social problems; participation in seminars and meetings with the education authorities and collaboration with other young teachers are the most common measures for professional adaptation of novice science teachers; more than half of the school teachers, according to science teachers, are ready for change and innovation and, and they provide support in the process of implementing innovations. The teachers report that the most common sources of stress are a feeling of responsibility for students' learning achievements, administrative work, and classroom preparation.

The theoretical significance of the study lies in its contribution to deeper scientific understanding of the current working conditions of teachers in science education that influence the effectiveness of instruction and the quality of educational programs. The findings of the research can help in developing a set of organizational and managerial measures for supporting science teachers in their work taking into account the specifics of science education.
\end{abstract}

Keywords: science teachers, teacher working conditions, school environment, teaching internship, TALIS.

(C) 2020 Vyacheslav V. Utemov

This is an open access article distributed under the terms of the Creative Commons Attribution License (CC BY 4.0), which permits unrestricted use, distribution, and reproduction in any medium, provided the original author and source are credited.

* Corresponding author. E-mail: vv_utemov@ @yatsu.ru 
Published by Kazan federal university and peer-reviewed under responsibility of IFTE-2020 (VI International Forum on Teacher Education)

\section{Introduction}

Disregarding the necessity to analyze and evaluate the current working conditions of science teachers may lead to an increased shortage of school teachers in the short term perspective. Whether the teachers are satisfied with the working conditions also influences the effectiveness of instruction in science education. The working conditions are characterized by the specifics of the teacher professional activities. First of all, it is the perception of teaching as a public good belonging to the public space. Consequently, the existing working conditions of school teachers should facilitate continuous professional development of science teachers. In this study, the term 'science teachers' is used to refer to teachers of Physics, Chemistry, Biology, Anatomy, Ecology, and other related subjects.

The working conditions of teachers can be negatively affected by the social environment where teachers work; organizational requirements related to physical and mental health of teachers; social relations between the teaching staff members. In general, the existing working conditions correlate with the level of professional motivation of science teachers and their career expectations.

The obvious conditions of employment of teachers are salaries and public recognition. These conditions have a positive effect on science teachers in terms of satisfaction with their work. However, considering the fact that the learning outcomes of students differ among teachers who work in the same conditions, it can be assumed that there is a connection between the learning outcomes and a set of conditions in which science teachers work. These conditions can have an impact on the effectiveness of instruction and the quality of education programs. Therefore, we studied a range of indicators characterizing the existing working conditions of science teachers, and then we developed a set of possible administrative support measures for science teachers.

\section{Purpose and objectives of the study}

Purpose of the study is aimed at analyzing the indicators of teacher working conditions in science education and developing a system of organizational and managerial measures to support the work of science teachers on the basis of these indicators 


\section{Literature review}

The research exploring the working conditions of science teachers is quite fragmented. The studies are devoted, to a large extent, to the issue of teacher effectiveness, but they also deal with the effectiveness of science teachers in general (Ye \& Singh, 2017).

Marioni et al. (2020) indicate that if teachers work in more than one school, it negatively affects the students' learning performance. The teachers working more hours in the same school achieve better learning outcomes. Other studies show strong associations between high student performance and the nature of school leadership (Sims, 2019).

According to Grant et al. (2019), teachers' working conditions, well-being and motivation are related to teachers' intentions to leave school or to remain. At the same time some studies reveal a negative association between real teaching practice and teaching career expectations unlike salary and societal evaluations (Han et al., 2018). At the same time, interventions in working conditions to sustain work ability among teachers should be tailored to employees' ages (Sottimano et al., 2017).

Ali (2018) stresses the need for creating the conditions in schools that support teachers' work. The working conditions should facilitate continued professional growth. At the same time it is shown that charter and traditional public school teachers perceive their working conditions to be similar in many respects, including principal leadership, sense of community and collegiality, classroom autonomy, opportunities for teachers to grow as professionals, and adequacy of instructional supplies (Ni, 2012). Teachers in charter schools experience lower levels of organizational commitment than teachers in traditional public schools (Ni, 2017). According to Malloy \& Wohlstetter (2003), charter schools, with increased autonomy, have more flexibility in creating better working conditions for teachers.

Geiger \& Pivovarova (2018) indicate that working conditions are an important factor affecting the teacher performance. They found that schools where teachers rated their working conditions as more satisfactory had lower teacher attrition rates. The study by Shimizu et al. (2011) showed that teacher attrition was associated with such factors of working conditions as interruptions, time pressure due to heavy workload, physically demanding job, extra work at home, poor communication with colleagues and occupational position not reflecting training. Therefore, some secondary schools provide more satisfactory working conditions than others, especially with regard to organizational functions and culture (Cucchiara et al., 2015). To create more satisfactory working conditions, the principal leadership takes into consideration teacher workload, teacher collaboration and teacher perceptions of student discipline (Toropova et al., 2020). Satisfaction with pedagogical work also depends on the gender of the teacher (Toropova et al., 
2020). Researchers found a stronger relationship between levels of collaboration and job satisfaction among male teachers. In addition, we noticed that the job satisfaction of teachers with underestimated assessments of their effectiveness becomes higher with the better school discipline. One more negative effect is voice disorders in teachers which are associated with work-related factors (Cantor Cutiva et al., 2013). It is possible to talk about the influence of teacher working conditions on their effectiveness in interaction (Jacques \& Osman, 2020). Gharechomaghlu \& Mirzadeh (2020) make a conclusion that working conditions are associated with teachers' motivation to work. There are also some other negative factors affecting teachers' performance. Head \& Pryiomka (2020), for instance, investigate the inconsistency of various teaching materials used for teaching in the same class.

There are two groups of negative factors in the work of teachers. The first group includes factors of teachers' social environment. The second group of factors includes those arising from the changed organizational requirements affecting the health of teachers and their personal relationships. (Alvarado \& Bretones, 2018).

Some studies investigate the working conditions for novice teachers. Good support from their colleagues has a positive effect on the quality of young teachers' administrative assignments. At the same time, mentoring by experienced teachers has a positive effect on the quality of teaching work that young teachers are to do. In addition, the studies note the difference in the attitudes to working conditions among teachers with different professional experience. (Pogodzinski, 2014). It should be noted that there are significant differences and inconsistencies in attaching teaching practice in teaching education (Chikunda, 2008). Different approaches directly affect the perception of the teaching conditions by novice teachers. Wellplanned and structured training for future teachers may help to avoid possible negative assessments by young teachers of their working conditions (Barkauskaite \& Pečiuliauskiene, 2011; Caldwell et al., 2020). Teaching practice benefited future teachers enabling them to gain valuable experience in the classroom and in general school management (Kwatubana \& Markbosch, 2019; Yin \& Jiang, 2014). In particular, there are some studies combining different approaches to teaching practice for pre-service teachers through online communities. (Zheng \& Zheng, 2011; Kuojun et al., 2019). Diversified and sustainable mechanisms for financing teaching practice must be created to improve the quality of preparation and management of teaching practice (Amollo et al., 2018). Zhang \& Zhang (2017) associate the quality of teaching practice for future teachers with their further teaching effectiveness.

Working conditions are associated with the characteristics of teaching as a professional activity. Zhang \& Zhan (2020) see teaching as a public good taking place in public space. 
Thus, there is a considerable research interest in teaching practice. However, there is quite scarce existing research on working conditions of science teachers (for example, only the teaching workload, or the principal leadership style is analyzed). Given the complex nature of teaching practice, there should be a more comprehensive investigation of the working conditions of science teachers.

\section{Methodology}

The study is based on the conceptual framework of the Teaching and Learning International Survey - 2018 (TALIS). The study can be divided into five important areas: styles of school management; professional development of a teacher; labor efficiency; motivation of teachers; teacher retention measures (Ainley \& Carstens, 2018). Each area examines the teachers' characteristics, their pedagogical work at the organizational and personal level. At the personal level, various practices are considered that affect the quality of teaching their students. At the organizational level, issues of administration, working conditions and the availability of various resources are distinguished.

The themes that allow us to characterize the working conditions of science teachers were selected as part of the present study. To obtain the analytical data, the following questions were included in the survey questionnaire for teachers:

- Indicate the degree of significance of the reasons for choosing the teaching profession.

- What adaptation measures were implemented when you started working in this school?

- Do the following statements refer to the teachers of your school?

- To what extent are the following sources of stress associated with your school?

Each question was aimed at obtaining the data for the analysis at both institutional and individual levels.

Thus, the chosen approach to investigating the working conditions of science teachers allows us to further compare the working conditions of science teachers with the data on other national education systems and other subject areas and to provide clear evidence to the suggested measures for supporting teachers.

The study is a comparative study of the data on the reasons for choosing the teaching profession, adaptation measures for novice teachers, and characteristics of school climate. The comparison allows us to develop a system of organizational and managerial measures to support the work of science teachers. 
The research data were obtained from the secondary schools (both urban and rural) in European Russia (2019-2020), analyzed, and generalized by means of:

- a questionnaire survey of 1146 secondary school employees including 310 teachers of science subjects. $70 \%$ of the respondents were teachers, $11 \%$ were school principals; $16 \%$ - deputy principals; $2 \%$ - school facilitators; other respondents make up $1 \%$. There $41 \%$ of respondents were from urban schools versus $59 \%$ of respondents from rural schools. The questionnaire contained a set of questions about the respondent's personality and four Likert scale questions on the following key aspects: the reasons for choosing the teaching profession, the implemented measures of adaptation for young teachers, and school climate;

- the analysis of working conditions of science teachers and their teaching practice through modeling and statistical analysis of the survey data.

The results of the analysis were presented at scientific and methodology conferences and discussed with education authorities, teachers, and representatives of executive bodies responsible for education (more than 90 participants)

The research consisted of four stages.

At the first stage, we looked into the present state of the problem in theory and in practice, and studied the characteristics of the teaching practice of science teachers. We studied and analyzed pedagogical and psychological literature on the problem of the research; carried out observation assessment, discussions and analysis of the existing working conditions of science teachers.

The second stage was devoted to determining the leading approach to the analysis of the working conditions of science teachers. The theoretical framework of the study was identified. The approaches to the research were presented as scientific reports and discussed in the course of conferences, including the conferences on methodology of teaching science disciplines.

The third stage was implemented alongside the second one. The survey of secondary school employees was conducted at this stage. The survey respondents were asked to complete a questionnaire consisting of four Likert scale questions and a few personality questions.

The system of indicators characterizing the existing working conditions of science teachers was analyzed at the fourth stage. Organizational and managerial measures to support the work of science teachers were identified and described. 


\section{Results}

The level of significance of the reasons for becoming a science teacher

To identify the degree of significance of the reasons for choosing the science teaching career, a four-point scale of significance was used. The respondents evaluated six possible reasons (Table 1).

Table 1. The level of significance of the reasons for choosing the science teaching career, $\%$

\begin{tabular}{|c|c|c|c|c|c|c|}
\hline $\begin{array}{c}\text { Reasons for choosing teaching as a } \\
\text { career }\end{array}$ & $\begin{array}{l}\text { Not } \\
\text { signif } \\
\text { icant }\end{array}$ & $\begin{array}{l}\text { Low } \\
\text { significa } \\
\text { nce level }\end{array}$ & $\begin{array}{c}\text { Middle } \\
\text { significanc } \\
\text { e level }\end{array}$ & $\begin{array}{l}\text { High } \\
\text { significan } \\
\text { ce level }\end{array}$ & $\begin{array}{c}\text { Integral } \\
\text { estimatio } \\
\mathrm{n} \text { for } \\
\text { science } \\
\text { teachers }\end{array}$ & $\begin{array}{c}\text { Integral } \\
\text { estimatio } \\
\mathrm{n} \text { for all } \\
\text { responde } \\
\mathrm{nts}\end{array}$ \\
\hline $\begin{array}{l}\text { Teaching allows achieving fast } \\
\text { career growth }\end{array}$ & 58 & 28 & 13 & 1 & 14 & 19 \\
\hline Teaching provides steady income & 21 & 37 & 37 & 5 & 33 & 35 \\
\hline Teaching is a safe job & 31 & 45 & 23 & 1 & 24 & 29 \\
\hline $\begin{array}{l}\text { Teaching workload (weekends, } \\
\text { shorter hours, vacation) is right for } \\
\text { my personal life }\end{array}$ & 16 & 25 & 47 & 12 & 42 & 44 \\
\hline $\begin{array}{l}\text { Teaching allows me to influence the } \\
\text { development of adolescents }\end{array}$ & 4 & 13 & 57 & 26 & 58 & 59 \\
\hline $\begin{array}{l}\text { Teaching allows me to be involved } \\
\text { in solving social problems }\end{array}$ & 13 & 27 & 50 & 10 & 42 & 44 \\
\hline
\end{tabular}

The reasons "Teaching allows me to influence the development of adolescents" and "Teaching allows me to be involved in solving social problems" have the highest values of the integral estimation. The lowest value is given to the reason "Teaching allows achieving fast career growth". It is seen that the opinion of all respondents (different representatives of school staff) is similar to the opinion expressed by science teachers. A more visible difference is only a higher estimation (5\% higher) of the reason for choosing teaching as a path for fast career growth. 


\section{Professional adaptation measures for novice science teachers}

Another important aspect of the collected data was the possibility to analyze the measures implemented in secondary schools to facilitate adaptation of young science teachers. The respondents were asked to choose from ten standard measures that can be implemented when a novice teacher enters a new position or during the first years of working at school (Table 2).

Table 2. Professional adaptation measures for novice science teachers, $\%$

\begin{tabular}{lcc}
\hline \multicolumn{1}{c}{ Adaptation Measures } & Implemented & Not implemented \\
\hline On-site courses/seminars that you attended & 87 & 13 \\
Online courses/seminars & 44 & 56 \\
Online events (e.g., online communities) & 24 & 76 \\
Scheduled meetings with the school leadership or experienced & 85 & 15 \\
teachers & & \\
Guidance provided by supervisors and/or more experienced & 69 & 31 \\
colleagues & 82 & 18 \\
Communication and collaboration with other new teachers & 39 & 61 \\
Training in a group with mentor teachers & 64 & 36 \\
Sharing instructional materials, manuals and guides & 24 & 76 \\
Lower teaching workload & 62 & 38
\end{tabular}

It is evident that courses/seminars, meetings with the school leadership, collaboration with other young teachers are the most common adaptation measures for novice science teachers implemented in schools. Online events and lower teaching workload are quite rare measures. The fact that only 4 out of 10 schools offer training in a group with a mentor teacher gives rise to concern. The results of the analysis for the entire data sample are similar to those of science teachers.

\section{School climate}

Two Likert scale questions aimed at evaluating school climate were offered to the respondents. At first, the respondents were asked to assess how strongly they agree with the statements in regard to their fellow teachers (Table 3 ). 
Table 3. School teachers' attitude to innovation, $\%$

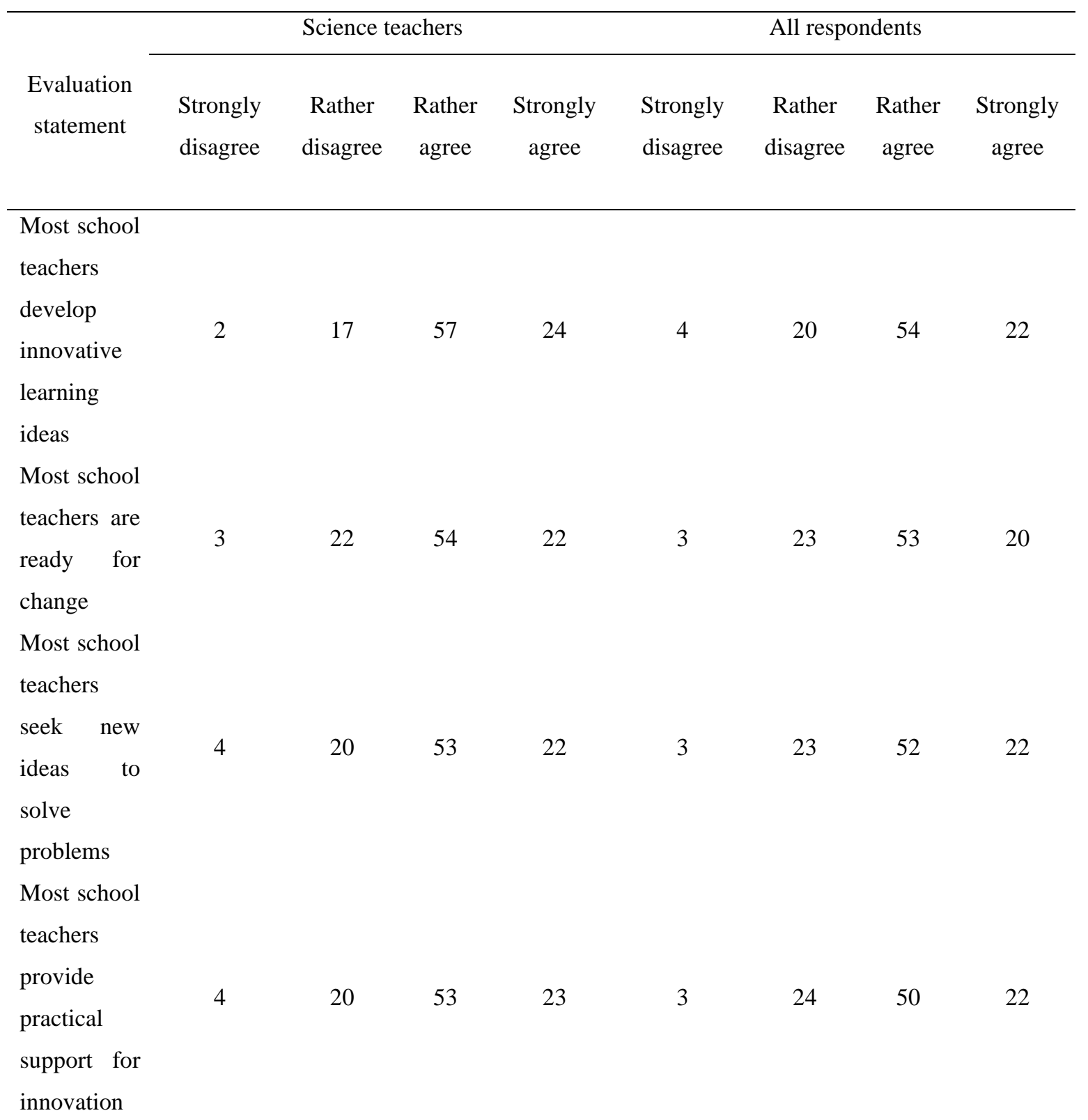

According to science teachers, more than half of their colleagues (from 54\% to 56\%) develop innovative strategies, are ready for change and provide support for introduced innovations. If we look at the data from all school staff, the percentage of such teachers is lower by $2-3 \%$. 
The second question asked to evaluate the sources of stress among school teachers on a four-point scale (Table 4).

Table 4. Sources of stress in the school, \%

\begin{tabular}{|c|c|c|c|c|c|}
\hline Stress sources & No & Rather No & $\begin{array}{c}\text { Rather } \\
\text { Yes }\end{array}$ & $\begin{array}{l}\text { Certainly } \\
\text { Yes }\end{array}$ & $\begin{array}{c}\text { Integral } \\
\text { assessment }\end{array}$ \\
\hline Too much classroom preparation & 10 & 39 & 37 & 14 & 42 \\
\hline Too many lessons (teaching workload) & 21 & 34 & 28 & 18 & 40 \\
\hline Too many special symbols, terminology & 24 & 48 & 22 & 5 & 29 \\
\hline $\begin{array}{l}\text { Too much administrative work (e.g., filling in } \\
\text { forms) }\end{array}$ & 10 & 24 & 35 & 30 & 54 \\
\hline $\begin{array}{l}\text { Additional responsibilities due to lack of } \\
\text { teachers }\end{array}$ & 19 & 38 & 23 & 19 & 40 \\
\hline Responsibility for students' achievements & 6 & 15 & 48 & 31 & 58 \\
\hline Maintaining classroom discipline & 23 & 35 & 33 & 10 & 35 \\
\hline Bullying or abuse by students/parents & 57 & 33 & 7 & 3 & 15 \\
\hline $\begin{array}{l}\text { Changing requirements from education } \\
\text { authorities }\end{array}$ & 26 & 34 & 25 & 14 & 36 \\
\hline Solving problems of parents or guardians & 24 & 43 & 27 & 6 & 30 \\
\hline $\begin{array}{l}\text { Lesson preparation for students with special } \\
\text { needs (disabled children, gifted children, } \\
\text { orphans, etc.) }\end{array}$ & 31 & 40 & 22 & 7 & 28 \\
\hline
\end{tabular}

The assessment of these indicators given by science teachers and by other school staff is similar. The respondents see the greatest degree of stress coming from such sources as being responsible for students' learning achievements, administrative work, and classroom preparation. The least degree of stress is recorded for bullying or abuse by students/parents.

\section{Discussions}

The survey of 1146 secondary school staff including 310 teachers of science subjects conducted in 20192020 draws the following conclusions: the most significant reasons for becoming a science teacher are the 
possibility to influence the development of children and solve social problems; participating in seminars and meetings with school leadership and collaboration with other young teachers are the most common adaptation measures for young science teachers in the school; more than half of school teachers develop innovation ideas, are ready for change and provide practical support for introduced innovations. The teachers report the greatest degree of stress coming from such sources as being responsible for students' learning achievements, administrative work, and classroom preparation.

The findings allow us to develop organizational and managerial measures aimed at providing support for the teachers of science education taking into consideration the working conditions of teachers in today's school, the factors determining the choice of a teaching profession, adaptation measures for young teachers, and characteristics of school climate.

Another aspect is to define and reduce to the minimum the range of working conditions of science teachers that affect the effectiveness of instruction and educational programs.

\section{Conclusion}

Thus, the study describes the factors characterizing the working conditions of science teachers based on an analysis of the data describing the reasons for choosing the teaching career, measures of adaptation for novice teachers, and characteristics of school climate.

Considering these factors, the following organizational and managerial measures aimed at providing support for science teachers can be suggested:

- enhancing the prestige of the teaching profession in the eye of students and their parents;

- training young teachers in groups with mentor teachers;

- creating online teacher communities;

- reconsidering the list of continuing education programs and training programs for science teachers and updating their content with a view to overcome possible sources of stress.

\section{References}

Ainley, J., \& R. Carstens (2018). Teaching and Learning International Survey (TALIS) 2018. Conceptual Framework. OECD Education Working Papers, No. 187. Paris: OECD Publishing. https://doi.org/10.1787/799337c2-en. 
Ali, T. (2018). Raising teachers' voices: An in-depth qualitative inquiry into teachers' working conditions and professional development needs in Khyber Pakhtunkhwa, a province of Pakistan. Teacher Development, 22(1), 78-104. doi:10.1080/13664530.2017.1308432

Alvarado, L. E., \& Bretones, F. D. (2018). New working conditions and well-being of elementary teachers in ecuador. Teaching and Teacher Education, 69, 234-242. doi:10.1016/j.tate.2017.10.015

Amollo, O. P., Lilian, G. K., \& Boniface, N. (2018). Preparation and management of teaching practice process at university of Nairobi, Kenya: Appropriateness of methods and resources. International Journal of Learning, Teaching and Educational Research, 17(8), 107-128. doi:10.26803/ijlter.17.8.7

Barkauskaite, M., \& Pečiuliauskiene, P. (2011). Constructivist insights on content and structure projection in university students' teaching practice [Universitetinès pedagoginès praktikos turinio ir struktūros projektavimo konstruktyvistinès įžvalgos]. Pedagogika, 96, 43-48.

Caldwell, H., Whewell, E., \& Heaton, R. (2020). The impact of visual posts on creative thinking and knowledge building in an online community of educators. Thinking Skills and Creativity, 36. doi:10.1016/j.tsc.2020.100647

Cantor Cutiva, L. C., Vogel, I., \& Burdorf, A. (2013). Voice disorders in teachers and their associations with work-related factors: A systematic review. Journal of Communication Disorders, 46(2), 143155. doi:10.1016/j.jcomdis.2013.01.001

Chikunda, C. (2008). Inconsistencies within attachment teaching practice in zimbabwe: Call for a participatory model. Mentoring and Tutoring: Partnership in Learning, 16(2), 141-146. doi:10.1080/13611260801916259

Cucchiara, M. B., Rooney, E., \& Robertson-Kraft, C. (2015). "I’ve never seen people work so hard!" teachers' working conditions in the early stages of school turnaround. Urban Education, 50(3), 259287. doi:10.1177/0042085913501896

Geiger, T., \& Pivovarova, M. (2018). The effects of working conditions on teacher retention. Teachers and Teaching: Theory and Practice, 24(6), 604-625. doi:10.1080/13540602.2018.1457524

Gharechomaghlu, M., \& Mirzadeh, H. (2020). Computational evaluation of the homogeneity of composites processed by accumulative roll bonding (ARB). Journal of Computational and Applied Research in Mechanical Engineering, 9(2), 351-358. doi:10.22061/jcarme.2018.3039.1324 
Grant, A. A., Jeon, L., \& Buettner, C. K. (2019). Relating early childhood teachers' working conditions and well-being to their turnover intentions. Educational Psychology, 39(3), 294-312. doi:10.1080/01443410.2018.1543856

Han, S. W., Borgonovi, F., \& Guerriero, S. (2018). What motivates high school students to want to be teachers? The role of salary, working conditions, and societal evaluations about occupations in a comparative perspective. American Educational Research Journal, 55(1), 3-39. doi:10.3102/0002831217729875

Head, J. C., \& Pryiomka, K. (2020). Accounting for mediatization in the era of individualized consequential accountability. Journal of Education Policy, 35(3), 421-440. doi:10.1080/02680939.2019.1566578

Jacques, M., \& Osman, G. (2020). The role of gender and education on decision-making. Studies in Business and Economics, 14(3), 117-130. doi:10.2478/sbe-2019-0048

Kuojun, Y., Peng, Y., Duyu, Q., \& Jiali, S. (2019). Teaching practice platform and innovation course construction for postgraduate majoring in electronics information. In C. Yi Xie (Ed.), 2018 IEEE Asia Pacific Conference on Circuits and Systems (APCCAS): proceedings (pp. 354-357). doi:10.1109/APCCAS.2018.8605673

Kwatubana, S., \& Markbosch. (2019). The value of teaching practice as perceived by postgraduate certificate in education (PGCE) students. South African Journal of Education, 39(2) doi:10.15700/saje.v39n2a1512

Malloy, C. L., \& Wohlstetter, P. (2003). Working conditions in charter schools: What's the appeal for teachers? Education and Urban Society, 35(2), 219-241. doi:10.1177/0013124502239393

Marioni, L. D. S., Freguglia, R. D. S., \& Menezes-Filho, N. A. (2020). The impacts of teacher working conditions and human capital on student achievement: Evidence from brazilian longitudinal data. Applied Economics, 52(6), 568-582. doi:10.1080/00036846.2019.1650885

Ni, Y. (2012). Teacher working conditions in charter schools and traditional public schools: A comparative study. Teachers College Record, 114(3).

Ni, Y. (2017). Teacher working conditions, teacher commitment, and charter schools. Teachers College Record, 119(6). 
Pogodzinski, B. (2014). Collegial support and novice teachers' perceptions of working conditions. Journal of Educational Change, 15(4), 467-489. doi:10.1007/s10833-013-9221-x

Shimizu, M., Wada, K., Wang, G., Kawashima, M., Yoshino, Y., Sakaguchi, H., . . A Aizawa, Y. (2011). Factors of working conditions and prolonged fatigue among teachers at public elementary and junior high schools. Industrial Health, 49(4), 434-442. doi:10.2486/indhealth.MS1206

Sims, S. (2019). Modelling the relationships between teacher working conditions, job satisfaction and workplace mobility. British Educational Research Journal. doi:10.1002/berj.3578

Sottimano, I., Viotti, S., Guidetti, G., \& Converso, D. (2017). Protective factors for work ability in preschool teachers. Occupational Medicine, 67(4), 301-304. doi:10.1093/occmed/kqx031

Toropova, A., Myrberg, E., \& Johansson, S. (2020). Teacher job satisfaction: The importance of school working conditions and teacher characteristics. Educational Review. doi:10.1080/00131911.2019.1705247

Ye, Y., \& Singh, K. (2017). The effect of working condition on math teacher effectiveness: Value-added scores and student satisfaction in teaching. Educational Research for Policy and Practice, 16(3), 283-295. doi:10.1007/s10671-016-9207-6

Yin, W., \& Jiang, Z. (2014). The integration of the idea of mathematic modeling into the teaching practice of discrete mathematics. Energy Education Science and Technology Part A: Energy Science and Research, 32(6), 5097-5102.

Zhang, F., \& Zhan, J. (2020). Understanding voice in chinese students' english writing. Journal of English for Academic Purposes, 45. doi:10.1016/j.jeap.2020.100844

Zhang, N., \& Zhang, Z. (2017). Research on teaching practice growth mode of students major in physical education. Eurasia Journal of Mathematics, Science and Technology Education, 13(10), 7111-7120. doi:10.12973/ejmste/78737

Zheng, Y., Li, L., \& Zheng, F. (2011). A conceptual model of online community of teaching practice for preservice teachers. doi:10.1007/978-3-642-24010-2_53 